University of Nebraska - Lincoln

DigitalCommons@University of Nebraska - Lincoln

Agronomy \& Horticulture -- Faculty Publications

Agronomy and Horticulture Department

2006

Predicting biomass partitioning to root versus shoot in corn and velvetleaf (Abutilon theophrasti)

Kimberly D. Bonifas

John L. Lindquist

University of Nebraska-Lincoln, jlindquist1@unl.edu

Follow this and additional works at: https://digitalcommons.unl.edu/agronomyfacpub

Part of the Plant Sciences Commons

Bonifas, Kimberly D. and Lindquist, John L., "Predicting biomass partitioning to root versus shoot in corn and velvetleaf (Abutilon theophrasti)" (2006). Agronomy \& Horticulture -- Faculty Publications. 377.

https://digitalcommons.unl.edu/agronomyfacpub/377

This Article is brought to you for free and open access by the Agronomy and Horticulture Department at DigitalCommons@University of Nebraska - Lincoln. It has been accepted for inclusion in Agronomy \& Horticulture -Faculty Publications by an authorized administrator of DigitalCommons@University of Nebraska - Lincoln. 


\section{Predicting biomass partitioning to root versus shoot in corn and velvetleaf (Abutilon theophrasti)}

Kimberly D. Bonifas

Department of Agronomy and Horticulture,

University of Nebraska, Lincoln, NE 68583-0817

John L. Lindquist

Corresponding Author. Department of Agronomy and Horticulture, University of Nebraska, Lincoln, NE 68583-0817; jlindquist1@unl.edu

\begin{abstract}
Knowledge of how plants will partition their new biomass will aid in understanding competition between crops and weeds. This study determined if the amount of biomass partitioned to the root versus the shoot can be predicted from tissue carbon $[C]$ and nitrogen $[N]$ concentrations and the daily gain in $C\left(G_{C}\right)$ and $N\left(G_{N}\right)$ for each unit shoot and root biomass, respectively. Pots measuring $28 \mathrm{~cm}$ diameter and $60 \mathrm{~cm}$ deep were embedded in the ground, and each contained one plant of either corn or velvetleaf. Each plant received one of three nitrogen treatments: 0,1 , or 3 $\mathrm{g}$ of nitrogen applied as ammonium nitrate in 2001 and 0,2 , or $6 \mathrm{~g}$ of nitrogen in 2002. Measurements of total above- and belowground biomass and tissue $[\mathrm{C}]$ and $[\mathrm{N}]$ were made at 10 different sample dates during the growing season. Fraction of biomass partitioned to roots $(\mathrm{Pr})$ was predicted from $[\mathrm{C}],[\mathrm{N}], \mathrm{G}_{\mathrm{C}}$, and $\mathrm{G}_{\mathrm{N}}$. Accurate prediction of the fraction of biomass partitioned to roots versus shoots was evaluated by comparing observed and predicted Pr across all treatments. The coordination model has potential as a reliable tool for predicting plant biomass partitioning. Normalized error values were close to zero for corn in 2001 and 2002 and for velvetleaf in 2001, indicating that biomass partitioning was correctly predicted.
\end{abstract}

Nomenclature: Velvetleaf, Abutilon theophrasti Medic. ABUTH; corn, Zea mays L.

Key words: Biomass partitioning, functional equilibrium, ontogenetic drift, optimal partitioning theory, phenology.
The distribution of biomass between roots and shoots influences the photosynthetic capacity and nutrient uptake of a plant, consequently affecting its relative growth rate (van der Werf 1996). When more new biomass is partitioned to shoots than roots, leaf weight ratio ( $\mathrm{g}$ leaf $\mathrm{g}$ total biomass $^{-1}$ ) will increase, causing concomitant increases in photosynthetic leaf area and relative growth rate. Conversely, the increase in leaf weight is likely to lead to a decrease in root weight ratio, reducing the plant's capacity to meet its demand for soil nitrogen, resulting in lower leaf nitrogen concentrations. Since photosynthetic rates are directly associated with leaf nitrogen concentration (Agren and Ingestad 1987; Hilbert 1990; Levin et al. 1989; Lindquist 2001a), the photosynthetic capacity of a plant, along with relative growth rate, will then decrease (van der Werf 1996).

These trade-offs that occur as a result of biomass partitioning can be viewed as a balance between root activity, or nitrogen uptake, and shoot activity, or photosynthesis. Optimal partitioning theory explains this balance by stating that plants will respond to changes in the environment by shifting biomass partitioning patterns to obtain the most limiting resource (Hilbert 1990; Mooney et al. 1985; Robinson 1986). According to optimal partitioning theory, plants facing limiting supplies of belowground resources will shift biomass partitioning toward more root production and less shoot production, and plants competing for light will shift biomass partitioning toward more shoot production and less root production.

A number of models have been introduced in an attempt to explain how plants will balance the partitioning of resources between roots and shoots (Agren and Ingestad 1987; Hilbert 1990; Hilbert and Reynolds 1991; Hilbert et al.
1991; Kastner-Maresch and Mooney 1994; Levin et al. 1989; Reynolds and Chen 1996). These models have similar foundation but represent progressively greater biological reality with time. Reynolds and Chen (1996) suggested that plants respond to varying environmental conditions by correcting the imbalance between nitrogen supply and carbon supply (Chen et al. 1993). In response, plants will coordinate the partitioning of new biomass to the roots and shoots to correct the imbalance.

Velvetleaf can cause up to $80 \%$ yield loss in corn (Lindquist et al. 1996), primarily because of competition for light (Lindquist and Mortensen 1999). A model that can accurately predict the biomass partitioning patterns of corn and velvetleaf would be beneficial in determining the resources for which weeds are likely to be most competitive. The ability to predict biomass partitioning patterns of plants in direct competition with one another has the potential to be a valuable tool in predicting the outcome of crop-weed competition.

The objective of this research was to determine if the amount of biomass partitioned to the root versus the shoot can be predicted from plant carbon $(\mathrm{C})$ and nitrogen $(\mathrm{N})$ concentrations using coordination theory as proposed by Reynolds and Chen (1996):

$$
\operatorname{Pr}=\frac{\frac{[N]}{\mathrm{G}_{\mathrm{N}}}}{\frac{[\mathrm{C}]}{\mathrm{G}_{\mathrm{C}}}-\frac{[\mathrm{N}]}{\mathrm{G}_{\mathrm{N}}}}
$$

where $\mathrm{Pr}$ is the fraction of biomass partitioned to the root and $[\mathrm{C}]$ and $[\mathrm{N}]$ are the carbon and nitrogen concentrations 
of plants, respectively. Specific shoot activity $\left(\mathrm{G}_{\mathrm{C}}\right)$ is daily gain in carbon for each unit of aboveground biomass ( $\mathrm{g} C$ $\mathrm{g}$ shoot $^{-1}$, and specific root activity $\left(\mathrm{G}_{\mathrm{N}}\right)$ is daily gain in nitrogen for each unit root biomass ( $\mathrm{g} \mathrm{N} \mathrm{g} \mathrm{root}{ }^{-1}$ ). Actual measurements of the fraction of biomass partitioned to roots will be compared to results predicted by Equation 1 using total above- and belowground biomass, leaf tissue carbon and nitrogen concentrations, and measured specific shoot and root activity values for both corn and velvetleaf.

\section{Materials and Methods}

Field experiments were conducted in 2001 and 2002 at the University of Nebraska in Lincoln. Plants were grown in large pots $(28 \mathrm{~cm}$ diameter by $60 \mathrm{~cm}$ deep) filled with a 50:50 sand: soil mixture and embedded in the ground to emulate the rhizosphere temperature environment of fieldgrown plants. Each pot had seven 1.8 -cm-diameter holes in their bottom to allow for drainage. Pots were buried flush with the soil surface on $1-\mathrm{m}$ centers. Rows of corn were planted between the rows of pots and around the edge of the site to more closely simulate field conditions and provide an added wind buffer for the treated plants in 2002. Total density, including potted plants, was 1 plant $\mathrm{m}^{-2}$ in 2001 and 5 plants $\mathrm{m}^{-2}$ in 2002 .

The experiment was arranged in three replicate blocks across a 3\% slope in a randomized complete block design. Blocks contained 10 replicate sample pots per treatment to accommodate for weekly destructive sampling. Each pot contained one corn or velvetleaf plant and received one of three $\mathrm{N}$ treatments. The $\mathrm{N}$ treatments administered were 0 , 1 , or $3 \mathrm{~g} \mathrm{~N}$ per pot in 2001 and 0 , 2, or $6 \mathrm{~g} \mathrm{~N}$ per pot in 2002. The $\mathrm{N}$ treatments were increased in 2002 because corn plants reached a maximum biomass of over $300 \mathrm{~g}$ plant in 2001. Assuming a whole plant $\mathrm{N}$ concentration of $2 \%$, a 300-g plant requires $6 \mathrm{~g} \mathrm{~N}$. Therefore, the increase was made to ensure adequate $\mathrm{N}$ supply for corn to reach its potential biomass in 2002. The $\mathrm{N}$ treatments were applied at planting in the form of ammonium nitrate dissolved in $500 \mathrm{ml}$ distilled water. Macro- and micronutrients other than $\mathrm{N}$ were nonlimiting and provided by means of a weekly addition of $250 \mathrm{ml}$ of a dilute nutrient solution containing $0.15 \mathrm{~g} \mathrm{KCl}, 0.31 \mathrm{~g} \mathrm{CaCl}_{2} \cdot 2 \mathrm{H}_{2} \mathrm{O}, 0.09 \mathrm{~g} \mathrm{MgSO}_{4} \cdot 7 \mathrm{H}_{2} \mathrm{O}$, $0.04 \mathrm{KH}_{2} \mathrm{PO}_{4}, 5.1 \times 10^{-4} \mathrm{~g} \mathrm{H}_{3} \mathrm{BO}_{3}, 5.9 \times 10^{-4} \mathrm{~g}$ $\mathrm{MnCl}_{2} \cdot 4 \mathrm{H}_{2} \mathrm{O}, 2.2 \times 10^{-4} \mathrm{~g} \mathrm{ZnSO}_{4} \cdot 7 \mathrm{H}_{2} \mathrm{O}, 5.0 \times 10^{-5} \mathrm{~g}$ $\mathrm{CuSO}_{4} \cdot 5 \mathrm{H}_{2} \mathrm{O}, 6.5 \times 10^{-5} \mathrm{~g} \mathrm{Na}_{2} \mathrm{MoO}_{4} \cdot 2 \mathrm{H}_{2} \mathrm{O}$, and $2.2 \times$ $10^{-3} \mathrm{~g} \mathrm{FeCl}_{3} \cdot 6 \mathrm{H}_{2} \mathrm{O}$. Soil water supply was measured weekly and added as needed with a drip irrigation system to maintain adequate soil moisture throughout the experiment.

Plants were destructively sampled weekly in all treatments for 10 wk during the growing season. Corn reached R1 to R2 (anthesis to blister), and velvetleaf began to flower at 10 wk. Sampling began 1 wk after emergence in 2001 and 2 wk after emergence in 2002. Plant height and growth stage were recorded, and plants were cut at the soil surface at each sampling date. Aboveground plant parts were separated into stems, leaves, dead leaves, and reproductive tissues. Sampled pots were pulled from the ground and roots carefully separated from the soil mixture using a gentle stream of water. After 10 wk of plant growth, there was no obvious constriction of root growth, and roots rarely grew outside the pot bottom. Above- and belowground tissues were dried at 60
C to constant weight and submitted to the University of Nebraska soil and plant test laboratory for tissue carbon and nitrogen analysis.

Soil samples were taken at each sampling date before extraction of the root systems by scooping approximately 200 $\mathrm{g}$ of soil from the top of each pot. Soil samples were weighed, dried, and reweighed to determine soil water content and ensure that water was being adequately and consistently supplied. Soil temperature was monitored both inside and outside pots to determine any temperature differences at five and three randomly selected locations in 2001 and 2002, respectively. Pairs (one inside and one outside the pot) of temperature loggers ${ }^{1}$ were placed $5 \mathrm{~cm}$ below the soil surface to log hourly temperatures throughout the experiment.

Specific shoot $\left(\mathrm{G}_{\mathrm{C}}\right)$ and root $\left(\mathrm{G}_{\mathrm{N}}\right)$ activity was calculated by averaging the carbon gain per unit shoot biomass and nitrogen gain per unit root biomass and dividing these values by the number of days between sampling dates. The coordination model of Reynolds and Chen (1996) was evaluated to determine its accuracy in predicting the fraction of biomass partitioned to roots between sampling dates. One of the major assumptions associated with this model is that $[\mathrm{C}]$ and $[\mathrm{N}]$ are constant throughout the plant. The validity of this assumption was tested by using both whole plant and leaf $[\mathrm{C}]$ and $[\mathrm{N}]$ to obtain predicted values of Pr.

Statistical analyses were conducted using the SAS System for Windows, version $8^{2}$. Effects of $\mathrm{N}$ treatment and time of sampling on corn and velvetleaf $[\mathrm{C}],[\mathrm{N}], \mathrm{G}_{\mathrm{C}}$, and $\mathrm{G}_{\mathrm{N}}$ were evaluated using the PROC mixed procedure (Littell et al. 1996). Only main effects are discussed because interactions between $\mathrm{N}$ treatment and time of sampling were not observed within species. Prediction of the fraction of biomass partitioned to root $(\mathrm{Pr})$ was evaluated by comparing observed $\operatorname{Pr}$ with predicted $\operatorname{Pr}$ calculated using both whole plant and leaf $[\mathrm{C}]$ and $[\mathrm{N}]$ values. Two measures of model accuracy were used. First, equality of the mean predicted and observed $\operatorname{Pr}$ values was tested using a two-sample $t$ test (Caton et al. 1999; Lindquist 2001b). Second, a plot of the normalized deviation $\left(\left[P_{i}-O_{i}\right] / O_{i}\right.$, where $P_{i}$ and $O_{i}$ are the predicted and observed $\operatorname{Pr}$ values, respectively) against observed $\operatorname{Pr}$ was used to observe patterns in predictive ability, similar to a residual plot (Mitchell 1997). The average of these normalized deviations (normalized average error, NAE) provides an estimate similar to a coefficient of variation (Lindquist 2001b). Therefore, the smaller the NAE, the greater the accuracy in predicting Pr. The sign of the NAE value $( \pm)$ indicates whether the model over- or underpredicts Pr. The NAE was calculated for each species at each nitrogen level using both whole plant and leaf [C] and $[\mathrm{N}]$ values (Table 3 ).

\section{Results and Discussion}

Measurements of gravimetric soil water content indicated adequate water availability throughout the experiment (data not shown). Average soil temperature inside and outside (23.1 C) pots did not differ in 2001, but soil temperature outside the pots was slightly greater $(24.0 \mathrm{C})$ than inside pots (23.5 C) in 2002. This temperature discrepancy was attributed to drought during the 2002 growing season. Slightly cooler soil temperatures inside the pots resulted 
TABLE 1. Corn and velvetleaf season-long average whole plant and leaf $\mathrm{N}$ and $\mathrm{C}$ concentrations (\%) with standard errors for both species in 2001 and 2002. Averages are reported for each nitrogen treatment and for all nitrogen treatments combined. Corn and velvetleaf whole plant and leaf $[\mathrm{C}]$ and $[\mathrm{N}]$ differed within all $\mathrm{N}$ treatments and years $(P<0.001)$. Within column, years and species means followed by different letters are different at $P<0.05$.

\begin{tabular}{|c|c|c|c|c|c|c|}
\hline \multirow[b]{3}{*}{ Year } & \multirow[b]{3}{*}{ Species } & \multirow{3}{*}{$\begin{array}{c}\text { N supply } \\
(\mathrm{G} \mathrm{N} \\
\left.\text { plant }^{-1}\right)\end{array}$} & \multicolumn{2}{|c|}{ Nitrogen } & \multicolumn{2}{|c|}{ Carbon } \\
\hline & & & $\begin{array}{l}\text { Whole } \\
\text { plant }\end{array}$ & Leaf & $\begin{array}{l}\text { Whole } \\
\text { plant }\end{array}$ & Leaf \\
\hline & & & \multicolumn{2}{|c|}{$(\% \mathrm{~N})$} & \multicolumn{2}{|c|}{$(\% \mathrm{C})$} \\
\hline \multirow[t]{6}{*}{2001} & Corn & 0 & $1.79 \mathrm{a}$ & $2.25 b$ & $36.81 \mathrm{a}$ & $40.92 \mathrm{a}$ \\
\hline & & 1 & $2.10 \mathrm{a}$ & $2.59 \mathrm{ab}$ & $37.07 \mathrm{a}$ & $40.89 a$ \\
\hline & & 3 & $2.39 \mathrm{a}$ & $3.02 \mathrm{a}$ & $37.00 \mathrm{a}$ & $41.26 \mathrm{a}$ \\
\hline & Velvetleaf & 0 & $2.66 \mathrm{a}$ & $3.40 \mathrm{~b}$ & $37.74 a$ & $38.73 a$ \\
\hline & & 1 & $2.65 \mathrm{a}$ & $3.34 \mathrm{~b}$ & $38.50 \mathrm{a}$ & $39.14 \mathrm{a}$ \\
\hline & & 3 & $2.97 \mathrm{a}$ & $4.07 \mathrm{a}$ & $38.38 \mathrm{a}$ & $39.23 a$ \\
\hline \multirow[t]{6}{*}{2002} & Corn & 0 & $1.97 \mathrm{~b}$ & $2.93 \mathrm{~b}$ & $35.69 \mathrm{a}$ & $41.59 \mathrm{a}$ \\
\hline & & 2 & $2.19 \mathrm{ab}$ & $3.16 \mathrm{ab}$ & $35.57 \mathrm{a}$ & $41.70 \mathrm{a}$ \\
\hline & & 6 & $2.55 \mathrm{a}$ & $3.58 \mathrm{a}$ & $36.00 \mathrm{a}$ & $41.81 \mathrm{a}$ \\
\hline & Velvetleaf & 0 & $2.08 \mathrm{~b}$ & $3.67 \mathrm{~b}$ & $35.26 \mathrm{a}$ & $40.08 \mathrm{a}$ \\
\hline & & 2 & $2.32 \mathrm{ab}$ & $3.93 \mathrm{~b}$ & $36.79 \mathrm{a}$ & $39.95 a$ \\
\hline & & 6 & $2.89 \mathrm{a}$ & $4.55 \mathrm{a}$ & $37.45 a$ & $40.22 \mathrm{a}$ \\
\hline
\end{tabular}

from the adequate and consistent water supply (Bonifas et al. 2005).

Leaf $[\mathrm{C}]$ and $[\mathrm{N}]$ were greater than whole plant $[\mathrm{C}]$ and $[\mathrm{N}]$ at all levels of $\mathrm{N}$ application for both species (Table 1). Therefore, it is possible that the coordination model of Reynolds and Chen (1996) will yield different results when predicting Pr from leaf versus whole plant $[\mathrm{C}]$ and $[\mathrm{N}]$. Corn and velvetleaf leaf $[\mathrm{N}]$ increased with increasing $\mathrm{N}$ supply in both years. Whole plant $[\mathrm{N}]$ tended to increase with $\mathrm{N}$ supply in both years, but means were not different at $\mathrm{P}<0.05$ in 2001 . In contrast, leaf and whole plant [C] did not vary across $\mathrm{N}$ treatments (Table 1 ). Corn and velvetleaf whole plant $[\mathrm{C}]$ did not differ at all sampling dates in 2001 (Figure 1). In 2002, early season corn and velvetleaf whole plant $[\mathrm{C}]$ did not differ, but velvetleaf $[\mathrm{C}]$ was greater than corn after 6 wk of growth. Velvetleaf whole plant $[\mathrm{N}]$ was greater than corn at all sampling times in both years.

Plant species with higher tissue nutrient concentrations of a limiting nutrient often have higher requirements for that resource and can be inferior competitors for it (Wedin and Tilman 1993). Velvetleaf clearly has a higher tissue $\mathrm{N}$ concentration than corn and, therefore, a higher requirement at equivalent biomass (Figure 1). Tilman et al. (1999) hypothesized that the density and cover of a weedy species could be controlled via adjustments to the ratios of supply of limiting resources. Therefore, velvetleaf density and cover may be reduced when nitrogen is the most important limiting resource. However, field competition experiments are required to test this hypothesis.

Specific shoot $\left(\mathrm{G}_{\mathrm{C}}\right)$ and root activity $\left(\mathrm{G}_{\mathrm{N}}\right)$ are indicators of the efficiency of carbon and nitrogen uptake efficiency, respectively. Corn and velvetleaf $\mathrm{G}_{\mathrm{C}}$ and $\mathrm{G}_{\mathrm{N}}$ generally decreased with time in both years (Figure 2). Corn $\mathrm{G}_{\mathrm{C}}$ was greater than velvetleaf between emergence and V7 (5 wk after planting) but smaller than velvetleaf between V8 and R2 (final sample) in 2001. Corn and velvetleaf $G_{C}$ did not differ at any sampling time in 2002. These results are somewhat surprising since the $\mathrm{C}_{4}$ photosynthetic pathway used

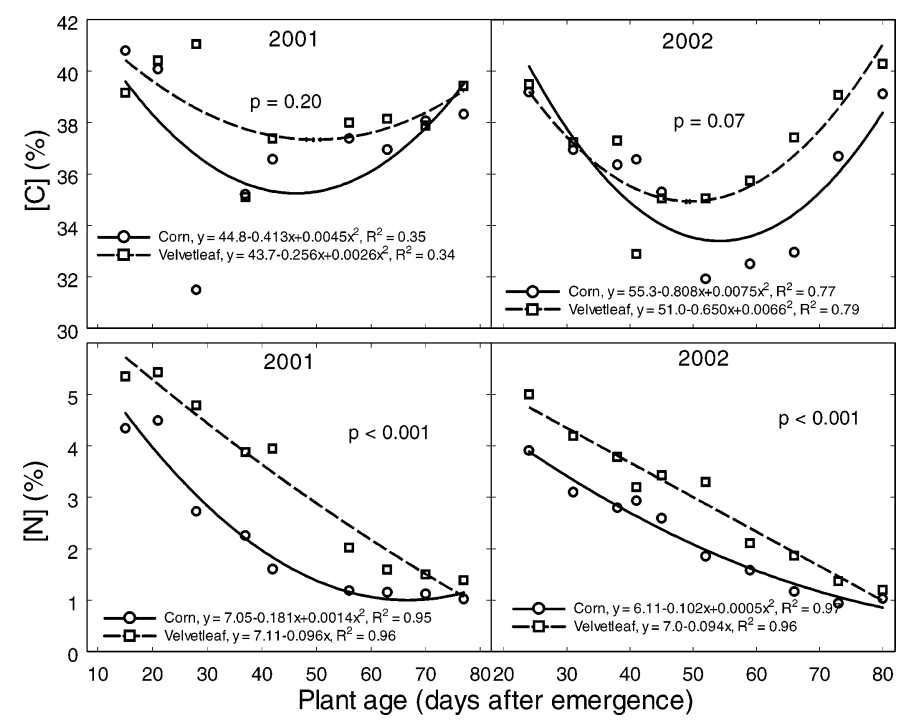

Figure 1. Corn and velvetleaf whole plant carbon (C) and nitrogen (N) concentration plotted as a function of plant age in days after emergence in 2001 and 2002. Curves represent best-fit second-order polynomial regressions. Probability values correspond to the test that plant nitrogen and carbon concentration did not differ between species.

by corn has greater photosynthetic efficiency (greater carbon gain per unit leaf area) than the $\mathrm{C}_{3}$ velvetleaf (Lindquist 2001a). However, Bonifas et al. (2005) and Harbur and Owen (2004) showed that corn had smaller leaf area ratio (leaf area per unit total biomass) than velvetleaf at similar sampling times. Therefore, the $\mathrm{C}$ gain per unit aboveground biomass may be smaller in corn because corn invests a greater proportion of its aboveground biomass in stem tissue than velvetleaf.

Velvetleaf $G_{N}$ was greater than corn at all sampling times in 2001 and between 5 and 9 wk after planting in 2002 (Figure 2). The greater $G_{N}$ indicates that velvetleaf had greater nitrogen uptake efficiency $(\mathrm{N}$ uptake per unit root biomass) than corn, which may be due to greater transpi-

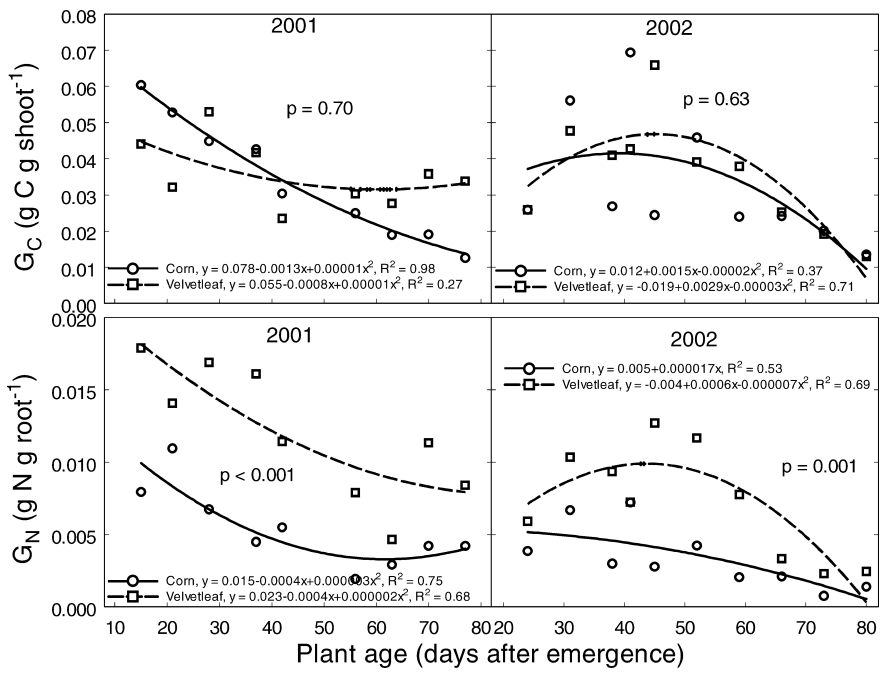

Figure 2. Corn and velvetleaf specific shoot activity $\left(G_{C}\right)$ and specific root activity $\left(\mathrm{G}_{\mathrm{N}}\right)$ plotted as a function of plant age in days after emergence in 2001 and 2002. Curves represent best-fit second-order polynomial regressions. Probability values correspond to the test that specific shoot activity and specific root activity did not differ between species. 
Table 2. Probability values for the test that there were no differences between observed and predicted fraction of biomass partitioned to corn and velvetleaf roots using whole plant and leaf $[\mathrm{C}]$ and $[\mathrm{N}]$ in 2001 and 2002.

\begin{tabular}{llcc}
\hline \multirow{2}{*}{ Year } & Species & Whole plant $[\mathrm{C}]$ and & \\
\hline 2001 & Corn & 0.138 & Leaf $[\mathrm{C}]$ and $[\mathrm{N}]$ \\
\hline \multirow{2}{*}{2002} & Velvetleaf & 0.352 & 0.299 \\
& Corn & 0.258 & 0.007 \\
& Velvelleaf & $<0.001$ & 0.281 \\
& &
\end{tabular}

ration since nitrate in soil is transported primarily by mass flow of soil solution (Nye and Tinker 1977). Greater transpiration could result if velvetleaf had more root surface area per unit root biomass (smaller root diameter), greater leaf area index $\left(\mathrm{m}^{2}\right.$ leaf $\mathrm{m}^{-2}$ ground), or more open stomata during daylight hours.

The greater $\mathrm{N}$ uptake efficiency of velvetleaf is contrary to the hypothesis that species with greater demand for a limiting nutrient are less competitive for that nutrient (Tilman et al. 1999). Bonifas et al. (2005) showed that velvetleaf root biomass was always smaller than that of corn but that velvetleaf partitioned proportionally more biomass to roots than corn between 2 and $6 \mathrm{wk}$ after planting when $\mathrm{N}$ supply was limiting. The combination of greater velvetleaf nitrogen uptake efficiency and increase in biomass partitioning to velvetleaf roots explains the greater velvetleaf whole plant $[\mathrm{N}]$ despite the smaller total root biomass throughout the experiment in both years. Therefore, when these species compete for nitrogen, the primary factor affecting competitive outcome may be competition for light since velvetleaf leaf area ratio declines when more biomass is partitioned to roots at low N supply (Bonifas et al. 2005).

Predicted fraction of biomass partitioned to root (Pr) differed when calculated using whole plant versus leaf $[\mathrm{C}]$ and [N] (data not shown). This had little effect on prediction of corn $\operatorname{Pr}$ because observed and predicted values were equivalent regardless of the method of prediction (Table 2). However, comparison of observed and predicted velvetleaf Pr differed depending on how the predicted Pr was calculated. Observed and predicted velvetleaf $\operatorname{Pr}$ differed when using leaf [C] and [N] in 2001 but were not different when whole plant values were used. In 2002, observed and predicted velvetleaf $\operatorname{Pr}$ differed when both whole plant and leaf $\mathrm{C}$ and $\mathrm{N}$ concentrations were used (Table 2).

Most normalized deviations between predicted and observed $\operatorname{Pr}$ values were near zero (Figure 3). Velvetleaf normalized deviations are more variable than corn in both years. Equation 1 tends to overpredict the fraction of biomass partitioned to the root for both species. This could be caused by a small percentage of root loss during root washing and extraction. Although the utmost care was taken to capture every root during washing and removal, it was estimated that between 2 and $4 \%$ of total root biomass was lost during washing, most of which consisted of root hairs and very fine roots. This small loss could deflate the values of observed Pr enough to make the model overpredict Pr.

Nitrogen treatment had no effect on the average of the normalized deviations (NAE; results not shown). Corn and velvetleaf $\operatorname{Pr}$ were predicted within 12 and 15\% (NAE = 0.12 and 0.15 ) of observed values, respectively, when whole

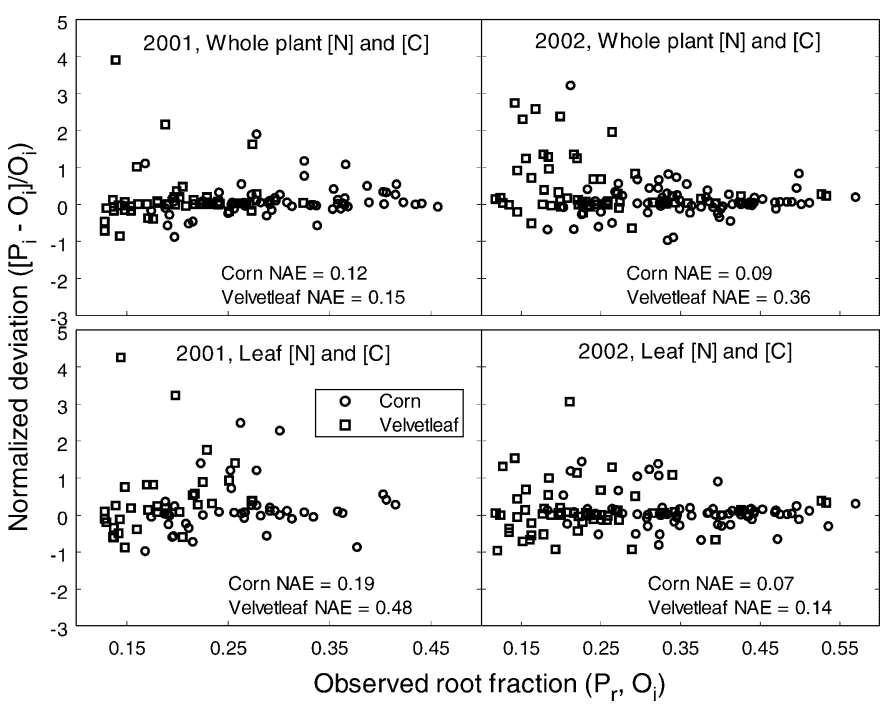

Figure 3. Normalized deviations between predicted and observed fraction of biomass partitioned to the root $\left(\left[P_{i}-O_{i}\right] / O_{i}\right)$ plotted as a function of the observed root fraction $(\operatorname{Pr})$ for corn and velvetleaf in 2001 and 2002. Predicted Pr was calculated using Equation 1, where either whole plant or leaf $[\mathrm{C}]$ and $[\mathrm{N}]$ were used. NAE represents the average of the normalized deviations.

plant $\mathrm{C}$ and $\mathrm{N}$ concentrations were used to predict $\operatorname{Pr}$ in 2001 (Figure 3). Corn Pr was predicted within 9 and 7\% of observed values when whole plant and leaf $[\mathrm{C}]$ and $[\mathrm{N}]$ were used in 2002. However, the NAE for velvetleaf was 300 and $100 \%$ greater than corn when whole plant and leaf $[\mathrm{C}]$ and $[\mathrm{N}]$ were used to calculate $\operatorname{Pr}$ in 2002, respectively.

The coordination model of Reynolds and Chen (1996) has potential for predicting biomass partitioning to corn and velvetleaf roots versus shoots. This approach would be useful in an ecophysiological model designed for the simulation of interplant competition for both light and soil nitrogen. Moreover, knowledge of how plants partition new growth to above- versus belowground tissues will give valuable insight into crop-weed competition. For example, a species that partitions more biomass to roots and less to shoots will be more competitive for belowground resources such as nitrogen and other nutrients but will be less competitive for light. This type of knowledge will be useful for developing cost-effective and environmentally sound integrated weed management strategies, including cultural practices that influence canopy architecture and fertility management.

\section{Sources of Materials}

${ }^{1}$ Optic StowAway, Onset Computer Corporation, Bourne, MA. 2 SAS Institute Inc., Cary, NC.

\section{Acknowledgments}

A contribution of the University of Nebraska Agricultural Research Division, Lincoln, NE. Journal Series No. 14566. This research was supported in part by funds provided by the Hatch Act and by the State of Nebraska.

\section{Literature Cited}

Agren, G. I. and T. Ingestad. 1987. Root : shoot ratio as a balance between nitrogen productivity and photosynthesis. Plant Cell Environ. 10:579_ 586. 
Bonifas, K. D., D. T. Walters, K. G. Cassman, and J. L. Lindquist. 2005. Nitrogen supply affects root: shoot ratio in corn and velvetleaf ( $\mathrm{Abu}$ tilon theophrasti). Weed Sci. 53:670-675.

Caton, B. P., T. C. Foin, and J. E. Hill. 1999. A plant growth model for integrated weed management in direct-seeded rice. II. Validation testing of water-depth effects and monoculture growth. Field Crops Res. 62:145-155.

Chen, J-L., J. F. Reynolds, P. C. Harley, and J. D. Tenhunen. 1993. Coordination theory of leaf nitrogen distribution in a canopy. Oecologia. 93:63-69.

Harbur, M. M. and M.D.K. Owen. 2004. Light and growth rate effects on crop and weed responses to nitrogen. Weed Sci. 52:578-583.

Hilbert, D. W. 1990. Optimization of plant root : shoot ratios and internal nitrogen concentration. Ann. Bot. 66:91-99.

Hilbert, D. W., A. Larigauderie, and J. F. Reynolds. 1991. The influence of carbon dioxide and daily photon-flux density on optimal leaf nitrogen concentration and root:shoot ratio. Ann. Bot. 68:365-376.

Hilbert, D. W. and J. F. Reynolds. 1991. A model allocating growth among leaf proteins, shoot structure, and root biomass to produce balanced activity. Ann. Bot. 68:417-425.

Kastner-Maresch, A. E. and H. A. Mooney. 1994. Modelling optimal plant biomass partitioning. Ecol. Mod. 75/76:309-320.

Levin, S. A., H. A. Mooney, and C. Field. 1989. The dependence of plant root : shoot ratios on internal nitrogen concentration. Ann. Bot. 64: $71-75$.

Lindquist, J. L. 2001a. Light-saturated $\mathrm{CO}_{2}$ assimilation rates of corn and velvetleaf in response to leaf nitrogen and development stage. Weed Sci. 49:706-710.

Lindquist, J. L. 2001b. Performance of INTERCOM for predicting Zea mays-Abutilon theophrasti interference across the north central USA. Weed Sci. 49:195-201.

Lindquist, J. L. and D. A. Mortensen. 1999. Ecophysiological characteris- tics of four corn hybrids and Abutilon theophrasti. Weed Res. 39:271285.

Lindquist, J. L., D. A. Mortensen, S. A. Clay, R. Schmenk, J. J. Kells, K. Howatt, and P. Westra. 1996. Stability of corn (Zea mays)-velvetleaf (Abutilon theophrasti) interference relationships. Weed Sci. 44:309313.

Littell, R. C., G. A. Milliken, W. W. Stroup, and R. D. Wolfinger. 1996. $\mathrm{SAS}^{\circledR}$ System for Mixed Models. Cary, NC: Statistical Analysis Systems Institute.

Mitchell, P. L. 1997. Misuse of regression for empirical validation of models. Agric. Syst. 54:313-326.

Mooney, H. A., A. J. Bloom, and F. S. Chapin III. 1985. Resource limitation in plants-an economic analogy. Annu. Rev. Ecol. Syst. 16:363392.

Nye, P. H. and P. B. Tinker. 1977. Solute Movement in the Soil-Root System. Los Angeles: University of California Press. 342 p.

Reynolds, J. F. and J-L. Chen. 1996. Modelling whole-plant allocation in relation to carbon and nitrogen supply: coordination versus optimization: opinion. Plant Soil 185:65-74.

Robinson, D. 1986. Compensatory changes in the partitioning of dry matter in relation to nitrogen uptake and optimal variations of growth. Ann. Bot. 58:841-48.

Tilman, E. A., D. Tilman, M. J. Crawley, and A. E. Johnston. 1999. Biological weed control via nutrient competition: potassium limitation of dandelions. Ecol. Applic. 9:103-111.

van der Werf, A. 1996. Growth analysis and photoassimilate partitioning. Pp. 1-20 in E. Zamski and A. A. Schaffer, eds. Photoassimilate Distribution in Plants and Crops: Source-Sink Relationships. New York: Marcel Dekker.

Wedin, D. and D. Tilman. 1993. Competition among grasses along a nutrient gradient: initial conditions and mechanisms of competition. Ecol. Monogr. 63:199-229.

Received June 20, 2005, and approved October 24, 2005. 